$$
\text { JOHN SELDEN: }
$$

MEASURES OF THE HOLY COMMONWEALTH IN SEVENTEENTH-CENTURY ENGLAND 
This page intentionally left blank 


\section{John Selden \\ MEASURES OF THE \\ HOLY COMMONWEALTH \\ IN SEVENTEENTH-CENTURY \\ ENGLAND}

Reid Barbour

UNIVERSITY OF TORONTO PRESS

Toronto Buffalo London 


\section{www.utppublishing.com}

(C) University of Toronto Press Incorporated 2003

Toronto Buffalo London

Printed in Canada

ISBN 0-8020-8776-0

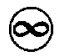

Printed on acid-free paper

\section{National Library of Canada Cataloguing in Publication}

Barbour, Reid

John Selden : measures of the Holy Commonwealth in seventeenth-century England / Reid Barbour.

Includes bibliographical references and index.

ISBN 0-8020-8776-0

1. Selden, John, 1584-1654. 2. Great Britain - Politics and

government - 1603-1649. 3. Constitutional history-England. 4. Great Britain - History - Stuarts, 1603-1714. I. Title.

DA390.1.S4B37 $2003 \quad 942.06^{\prime} 092 \quad$ C2003-900215-2

University of Toronto Press acknowledges the financial assistance to its publishing program of the Canada Council for the Arts and the Ontario Arts Council.

University of Toronto Press acknowledges the financial support for its publishing activities of the Government of Canada through the Book Publishing Industry Development Program (BPIDP). 
For Jessica Lynn Wolfe 
This page intentionally left blank 